\title{
EMARA: Indonesian Journal of Architecture
}

Vol 4 No 2 - December 2018

ISSN 2460-7878, 2477-5975 (e)

\section{Penerapan Prinsip Islamic Garden pada Taman Kota di Surabaya}

\author{
Oktavi Elok Hapsari, Muhamad Ratodi, Rafiika Narulita Sari \\ Prodi Arsitektur Universitas Islam Negeri Sunan Ampel, Surabaya, Indonesia \\ oktagaudielok@gmail.com,mratodi@uinsby.ac.id, rafiika26@gmail.com \\ doi.org/10.29080/eija.v4i2.433
}

\begin{abstract}
The park as a city open space, is believed to be able to contribute both micro and macro to urban quality and its population. As a comprehensive teaching, Islam has also set guidelines for structuring landscapes with Islamic Garden principles. This study aims to observe the application of the nine principles of Islamic garden with various parameters in urban parks throughout Surabaya, a city that is widely known for its city parks. With a purposive sampling method, five active city parks in five areas of Surabaya have been used as an observation objects. The observations has showed that the parameter of order and pattern have been fulfilled throughout the observation locations, specifically related to the balance aspects of the amount of Green and Non-Green Open Space while geometric formation found in almost all city gardens observed. Whereas the Bungkul Park and Flora Park became the city parks which most Islamic Garden parameters applied in the City of Surabaya.
\end{abstract}

Keywords: city park, islamic garden, islamic garden parameters, Surabaya

Abstrak: Taman sebagai ruang terbuka kota, dipercaya mampu memberikan kontribusi baik secara makro maupun mikro terhadap kualitas perkotaan dan penduduknya. Sebagai ajaran yang komprehensif, Islam pun telah mengatur panduan penataan lanskap dengan prinsip Islamic Garden. Penelitian ini bertujuan untuk mengobservasi bagaimana penerapan sembilan prinsip taman Islam dengan sejumlah parameter pada tamantaman kota di Surabaya, kota yang dikenal luas dengan keberadaan taman-taman kotanya. Dengan metode purposive sampling, ditentukan lima taman kota aktif pada lima wilayah kota Surabaya yang dijadikan objek pengamatan. Hasil observasi menunjukkan bahwa parameter urutan dan pola telah terpenuhi pada keseluruh lokasi amatan, khususnya terkait aspek keseimbangan besaran Ruang Terbuka Hijau dan Ruang Terbuka NonHijau serta Bentukan geometri yang terdapat di hampir seluruh taman. Sedangkan Taman Bungkul dan Taman Flora menjadi taman kota yang paling banyak memenuhi penerapan parameter Islamic Garden di Kota Surabaya

Kata Kunci: taman kota, taman islami, parameter taman islami, Surabaya

\section{PENDAHULUAN}

Islam merupakan agama yang diturunkan oleh Allah SWT sebagai agama rahmatan lil 'alamiin, yang telah mengatur segala aspek kehidupan secara menyeluruh, termasuk dalam ranah arsitektur. Hal tersebut berpengaruh terhadap aktifivitas hingga pengelolaan taman. Taman dalam Islam pada umumnya dimaknai sebagai perwujudan gambaran surga di bumi yang tertuang dalam berbagai ayat pada Al-Qur'an, Namun penggambaran tersebut belum dapat dijadikan referensi secara eksplisit dalam perancangan sebuah taman. Walidaen et al (2017) berpendapat gambaran surga dalam ayat-ayat Al-Qur;an dan Hadits hanya dapat digunakan sebagai inspirasi bentukan taman islam. Lebih lanjut Qardhawi dalam Jannah (2015) menyatakan bahwa taman sebagai bagian dari muamalah memiliki kaidah hukum yang memperbolehkan segala sesuatu berkenaan dengan seni dan kreativitas selama tidak melanggar hal-hal yang memang telah secara syar'i diharamkan.
Dalam konteks perkotaan, keberadaan taman sangat berperan penting dalam membentuk kualitas kehidupan masyarakatnya (Francis et al, 2012). Surabaya sendiri telah dinobatkan sebagai kota terbesar kedua di Indonesia yang dianggap berhasil dalam pembangunan ruang terbuka hijaunya, termasuk taman-taman kota (Iswari, 2014). Saat ini Surabaya memiliki tidak kurang dari 350 taman kota yang terbagi menjadi dua jenis yaitu taman aktif dan taman pasif (Yolanda \& Masnuna, 2015). Keberadaan taman-taman tersebut pun cukup ramai dikunjungi berbagai kalangan dengan berbagai macam aktivitas.

Konsep Islamic Garden sendiri merupakan sebuah konsep taman islami yang terinspirasi dari tamantaman surga yang ada dalam Al-Qur'an. Jannah et al (2015) dalam penelitiannya telah mengembangkan sejumlah parameter tentang kriteria taman islam berdasarkan Al-Qur'an dan Hadits. Parameter tersebut adalah urutan (order), ruang (space), bentuk (form), tekstur (texture), pola (pattern), cahaya (light), 
pergerakan (movement), elemen taman (garden element) dan pengguna (user). Dengan tujuh puluh enam persen penduduk kota Surabaya beragama Islam (BPS Provinsi Jawa Timur, 2017) serta keinginan dari pemerintah kota untuk membangun lebih banyak lagi taman di kota Surabaya (Viva, 2018) maka akan menarik untuk ditelaah bagaimana penerapan prinsip Islamic Garden pada taman-taman kota di Surabaya. Hasil penelaahan diharapkan akan mampu menimbulkan kesadaran sebagai umat muslim untuk mengembangkan dan mengaplikasikan prinsip taman Islami dalam pembangunan taman kota, khususnya di kota Surabaya.

\section{METODE PENELITIAN}

Penelitian ini menggunakan metode deskriptif dengan pendekatan kualitatif. Metode ini digunakan untuk menjabarkan konsep taman islami dan menentukan parameter penelitian (lihat tabel 1). Lembar observasi (observasion sheet) digunakan untuk mengamati pemenuhan setiap parameter di lokasi penelitian. Penentuan lokasi penelitian dilakukan dengan metode purposive sampling, dimana peneliti menentukan satu taman kota pada setiap wilayah kota Surabaya yang memiliki karakter taman aktif. Adapun lokasi penelitian adalah Taman Bulak di Surabaya Utara, Taman Flora di Surabaya Selatan, Taman Pakal di Surabaya Barat, Taman Bungkul di Surabaya Timur dan Taman Prestasi di pusat kota Surabaya. Data yang diperoleh dari hasil observasi kemudian dilakukan tabulasi untuk memperoleh gambaran tentang penerapan prinsip Islamic Garden pada taman kota di Surabaya.

Tabel 1. Parameter Islamic Garden yang diobservasi

\begin{tabular}{|c|c|c|c|}
\hline No. & Prinsip & Penjelasan & Penerapan \\
\hline 1. & Urutan & Geometris dan seimbang & $\begin{array}{l}\text { Bentukan geometris pada } \\
\text { site dan furnitur taman }\end{array}$ \\
\hline 2 & Ruang & $\begin{array}{l}\text { Ukuran bervariasi sesuai penggunaan dan dapat dimanfaatkan } \\
\text { oleh beragam pengguna pada saat yang bersamaan.. }\end{array}$ & $\begin{array}{l}\text { Zonasi yang jelas dan } \\
\text { ruang yang cukup }\end{array}$ \\
\hline 3. & Bentuk & $\begin{array}{l}\text { Bentukan yang digunakan tidak boleh menyerupai ciptaan } \\
\text { Allah SWT (manusia dan hewan) yang memungkinkan untuk } \\
\text { disembah atau mempersekutukan Allah SWT }\end{array}$ & $\begin{array}{l}\text { Terdapat patung yang } \\
\text { menyerupai bentukan } \\
\text { makhluk hidup secara } \\
\text { utuh }\end{array}$ \\
\hline 4. & Tekstur & $\begin{array}{l}\text { Pengembangannya lebih pada tekstur yang bersifat alami } \\
\text { selama bermanfaat dan tidak melanggar hal yang disyariatkan }\end{array}$ & \\
\hline 5. & Pola & $\begin{array}{l}\text { Pada umumnnya berupa bentukan Arabesque yang } \\
\text { terinspirasi dari pola tumbuhan dan kaligrafi. Menghindari } \\
\text { penggambaran manusia dan hewan, harus diperhatikan tujuan } \\
\text { penggunaannya agar tidak digunakan untuk mempersekutukan } \\
\text { Allah SWT. }\end{array}$ & $\begin{array}{l}\text { Terdapat bentukan } \\
\text { arabesque maupun pola } \\
\text { geometri pada taman }\end{array}$ \\
\hline 6. & Cahaya & $\begin{array}{l}\text { Taman yang teduh dan tidak terdapat penggunaan cahaya } \\
\text { yang terlalu panas. Terdapat naungan untuk melindungi dari } \\
\text { cahaya / panas }\end{array}$ & $\begin{array}{l}\text { Terdapat pencahayaan } \\
\text { alami dan buatan serta } \\
\text { naungan pada taman }\end{array}$ \\
\hline 7. & Pergerakan & $\begin{array}{l}\text { Pergerakan meliputi alur pengunjung dan air. Bagi pengunjung, } \\
\text { taman diharapkan memiliki pola sirkulasi yang jelas dan } \\
\text { terarah, hal ini merujuk pada penggambaran surga, yang } \\
\text { menjelaskan bahwa salah satu hal yang paling diinginkan oleh } \\
\text { manusia sebagai pengguna taman adalah kemudahan akses } \\
\text { dalam memenuhi kebutuhannya pada taman }\end{array}$ & $\begin{array}{l}\text { Bagaimana aksesibilitas } \\
\text { menuju taman dan } \\
\text { bagaimana sirkulasi di } \\
\text { dalam taman }\end{array}$ \\
\hline 8 & $\begin{array}{l}\text { Elemen } \\
\text { taman }\end{array}$ & $\begin{array}{l}\text { Elemen utama adalah air dan naungan . Selain itu terdapat } \\
\text { elemen yang disebutkan dalam penggambaran surga, } \\
\text { mencakup elemen lunak (air, vegetasi dan buah-buahan), } \\
\text { serta hewan, maupun elemen keras (bangunan - bangunan } \\
\text { taman, pintu-pintu, serta elemen keras lainnya seperti bantal, } \\
\text { permadani , dipan, gelas, piala, piring , bejana dan } \\
\text { sebagainya. }\end{array}$ & $\begin{array}{l}\text { Ketersediaan elemen } \\
\text { lunak dan keras untuk } \\
\text { mengakomodir } \\
\text { kebutuhan pengunjung }\end{array}$ \\
\hline 9. & Pengguna & $\begin{array}{l}\text { Tidak terdapat kriteria pengguna taman yang khusus. Taman } \\
\text { dapat bersifat publik atau privat dan terbuka bagi semua } \\
\text { pengguna selama tidak melanggar batasan syariah: } \\
\text { berpenampilan dan beraktivitas sesuai dengan hukum Islam. }\end{array}$ & $\begin{array}{l}\text { Pengguna taman tidak } \\
\text { menyalahi syariah ketika } \\
\text { beraktivitas di dalam } \\
\text { taman }\end{array}$ \\
\hline
\end{tabular}

Sumber: Jannah (2015) 


\section{HASIL DAN PEMBAHASAN}

\subsection{Hasil observasi lima taman kota Surabaya Taman Flora}

Secara umum, prinsip Islamic garden telah diterapkan pada pembangunan taman Flora yang dibuat untuk tujuan ihya yaitu mengembangkan kemakmuran kehidupan suatu daerah melalui tahsin al 'ard yaitu melakukan penghijauan di bumi sehingga terwujud islah atau kemakmuran dan kesejahteraan warga kota Surabaya. Bentukan geometri yang merupakan ciri khas Islamic garden terdapat pada taman Flora diantaranya adalah bentuk segi enam beraturan, persegi panjang, lingkaran dan setengah lingkaran yang teraplikasikan pada beberapa elemen taman, seperti pada sitting group (gambar 1), bentuk lingkaran pada kolam serta bentukan geometris lain pada penataan vegetasi dan jalur sirkulasi.

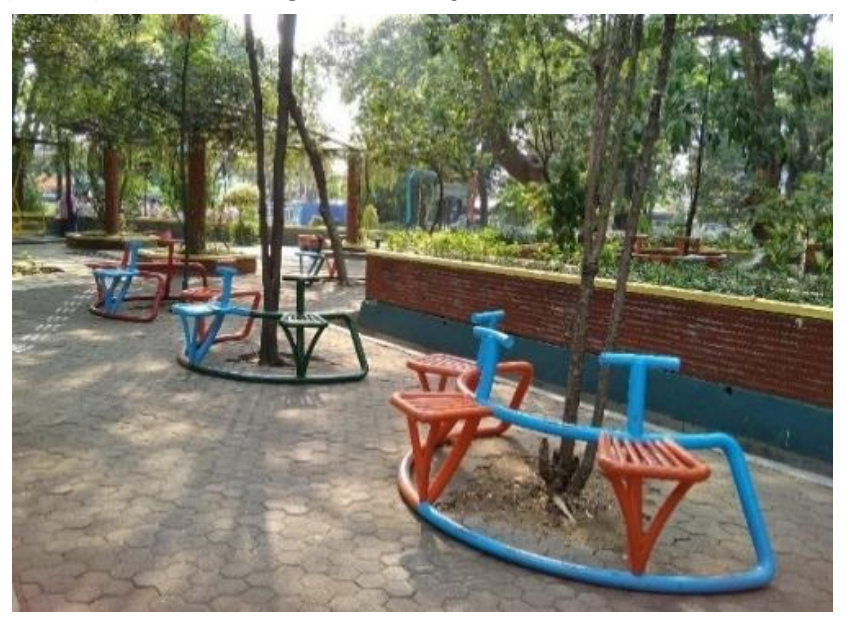

Gambar 1. Bentuk elemen sitting group (sumber: hasil observasi, 2018)

Prinsip Islamic Garden terlihat dari keseimbangan antara jumlah luas Ruant Terbuka Hijau (RTH) dengan Ruang Terbuka Non Hijau (RNTH). Hal ini menandakan bahwa adanya keseimbangan antara hablummina Allah, hablumminal'alamin, dalam bentuk merawat dan menjaga bumi Allah dengan banyaknya $\mathrm{RTH}$, serta hablumminannas dengan banyaknya aktivitas yang meningkatkan adanya hubungan harmonis dan meningkatkan ukhuwah antar manusia.

Luas lahan yang tergolong besar dan zonasi ruang yang tertata memungkinkan bagi pengunjung untuk melakukan aktivitas dalam jumlah yang banyak dan waktu yang bersamaan. Pengunjung dapat melihat penataan zonasi dari papan informasi yang tersedia pada area pintu masuk taman sehingga memudahkan pengunjung untuk beraktivitas di dalam taman (gambar 2), Pada saat observasi lapangan, selain aktivitas rekreasi dan olah raga pada taman, terdapat aktivitas lain seperti kegiatan sosial mewarnai paving block dan membersihkan ranting yang berserakan di area selatan dari BPJS Karimunjawa dan aktivitas pendidikan lomba pramuka dari salah satu sekolah dasar. Masing-masing kegiatan tidak saling mengganggu karena zonasi ditata dengan baik untuk memudahkan masing-masing aktivitas

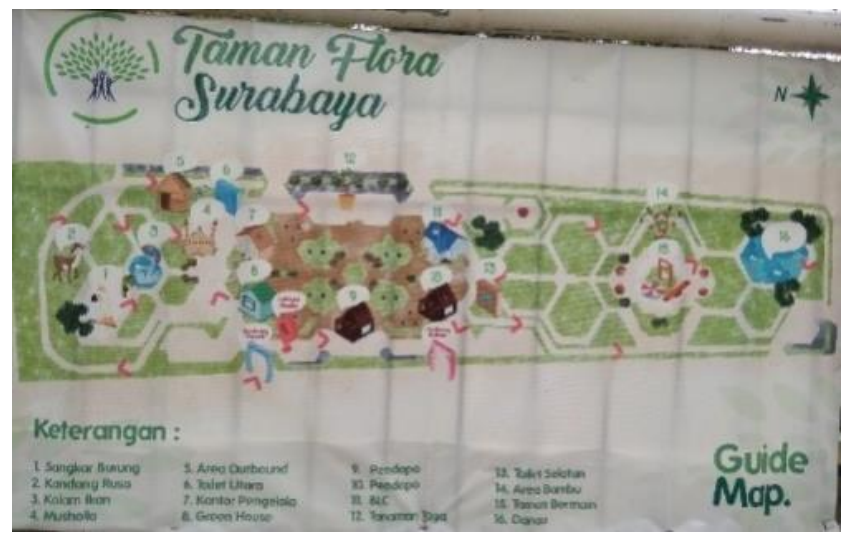

Gambar 2. Siteplan dan informasi zonasi bagi pengunjung (sumber: hasil observasi, 2018)

Pencahayaan pada taman, baik alami maupun buatan teraplikasi secara maksimal. Pencahayaan alami didapat dari sinar matahari yang diakomodir dengan pepohonan yang teduh dan keberadaan shelter dengan kumpulan tumbuhan Janda Merana membuat naungan tersendiri untuk pengunjung yang beraktivitas pada taman (gambar 3). Pencahayaan buatan didapatkan dari keberadaan lampu taman yang tersebar di beberapa titik di taman Flora. Karena tidak beroperasi sampai malam hari, lampu taman lebih berfungsi untuk penjagaan keamanan.

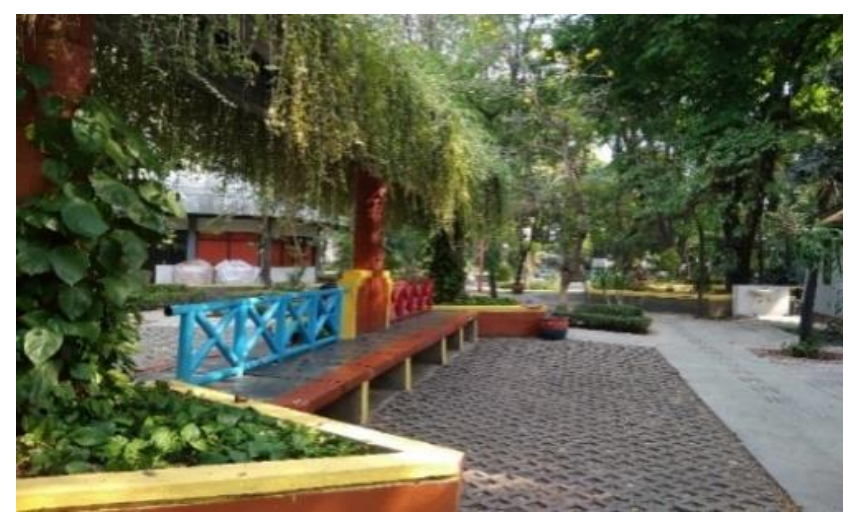

Gambar 3. Shelter yang dinaungi oleh kumpulan tanaman Janda Merana (sumber: hasil observasi, 2018)

Taman Flora memiliki kemudahan akses, hal ini terlihat dari banyaknya jalan yang dapat diakses menuju taman yaitu dari jalan raya Manyar, jalan raya Bratang dan jalan raya Ngagel. Taman ini juga berdekatan dengan terminal angkutan umum Bratang, sehingga pilihan moda transportasi yang tersedia juga beragam. Sedangkan pola sirkulasi di area taman Flora secara jelas mengarahkan pengunjung untuk bergerak dari zona yang satu ke zona lainnya. Dimensi dan material jalur sirkulasi beraneka ragam, dengan 
sirkulasi utama berukuran 3 meter dan berbahan keramik serta paving (gambar 4). Lebar sirkulasi ini memudahkan pengunjung untuk berjalan bersama dan apabila berpapasan tidak perlu berdesakan. Sedangkan sikulasi sekunder memiliki lebar sekitar 12 meter untuk area jogging dan taman kecil didalamnya

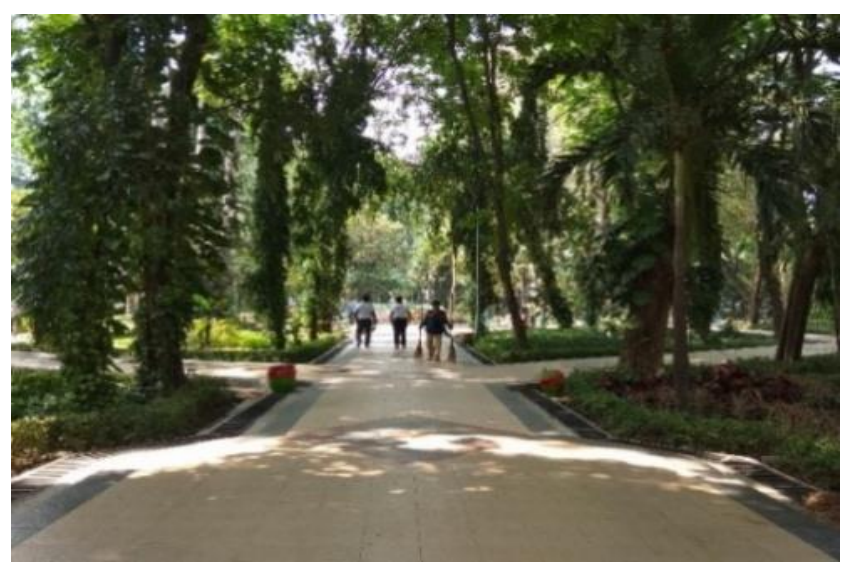

Gambar 4. Jalur sirkulasi utama (sumber: hasil observasi, 2018)

Elemen lunak pada taman Flora ditunjukan dalam bentuk kolam air, beberapa jenis satwa diantaranya rusa, ikan dan aneka jenis burung yang terletak di zona fauna, serta tanaman toga (tanaman obat keluarga) dan tanaman hias. Setiap pohon diberi label yang berisi informasi mengenai nama dan jenis pohon tersebut, sehingga menjadi unsur edukasi tambahan bagi pengunjung. Pengunjung pun dapat secara leluasa berinteraksi dengan satwa-satwa yang ada di Taman Flora ini (gambar 5). Untuk elemen keras diwujudkan dalam bentuk bangunan seperti pendopo, mushola, kantor, perpustakaan, toilet dan fasilitas penunjang lainnya.

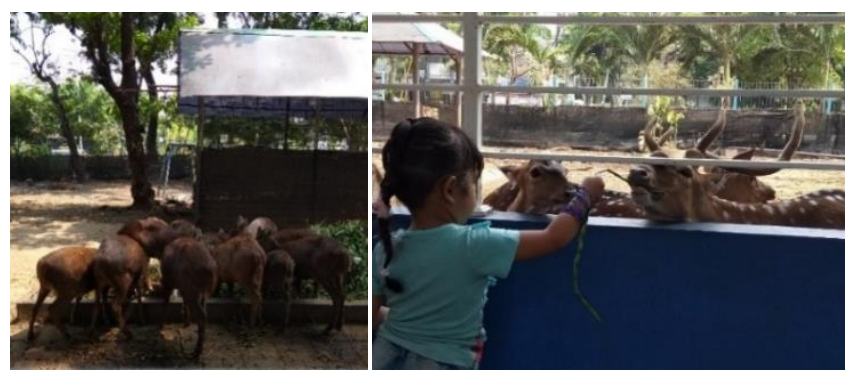

Gambar 5. Keberadaan satwa dan interakasi pengunjung dengan satwa di Taman Flora (sumber: hasil observasi, 2018)

Adanya elemen - elemen ini selain sebagai sarana edukasi, rekreasi dan penunjang juga sebagai pengingat akan adanya nikmat yang Allah SWT berikan kepada manusia (hablummina Allah). Elemen keras dan elemen lunak ini selain berfungsi sebagai setting kegiatan pengguna tapi sebagai setting untuk memunculkan interaksi antara para pengunjung,s sesuai dengan konteks silaturahmi dan hablumminannas.
Pengunjung taman Flora lebih ramai pada saat akhir pekan dan hari libur. Para pengunjung terdiri dari berbagai kalangan dan tingkatan usia, mulai dari anakanak sampai dengan orang dewasa dan lansia. Adapun aktivitas yang terdapat di taman Flora cukup beragam. Diantaranya aktivitas rekreasi seperti berjalan-jalan, memperkenalkan anak dengan dunia hewan dan berolahraga. Aktivitas sosial seperti kerja bakti dan penggalangan dana, lomba- lomba hingga acara yang bersifat institusional seperti diklat dan lain sebagainya. Aktivitas yang dilakukan di taman Flora dapat dikatagorikan sebagai aktivitas islah, yaitu meningkatkan kemakmuran di bumi. Hal ini dikarenakan aktivitas yang ada di taman Flora berkaitan dengan peningkatan kesejahteraan, baik secara material misalnya dengan kegiatan berdagang dan kegiatan berolahraga yang menyebabkan pengunjung menjadi sehat secara jasmani maupun rohani. Sebagai batasan dalam beraktivitas dan mengeksplorasi fasilitas yang ada di taman, terdapat signage atau rambu - rambu berupa himbauan dan pembelajaran (gambar 6).

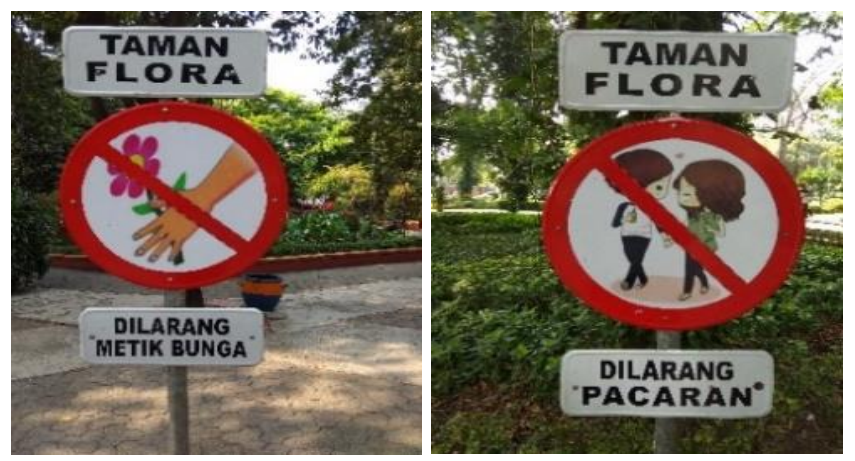

Gambar 6 Signage dalam taman yang mengatur perilaku pengguna (sumber: hasil observasi, 2018)

\section{Taman Pakal}

Bentukan geometris yang terdapat pada taman Pakal diantaranya adalah persegi panjang dan lingkaran lahan yang diaplikasikan pada jalur sirkulasi, dan bentuk elemen taman seperti sculpture, sitting group serta penataan vegetasi taman (gambar 7).

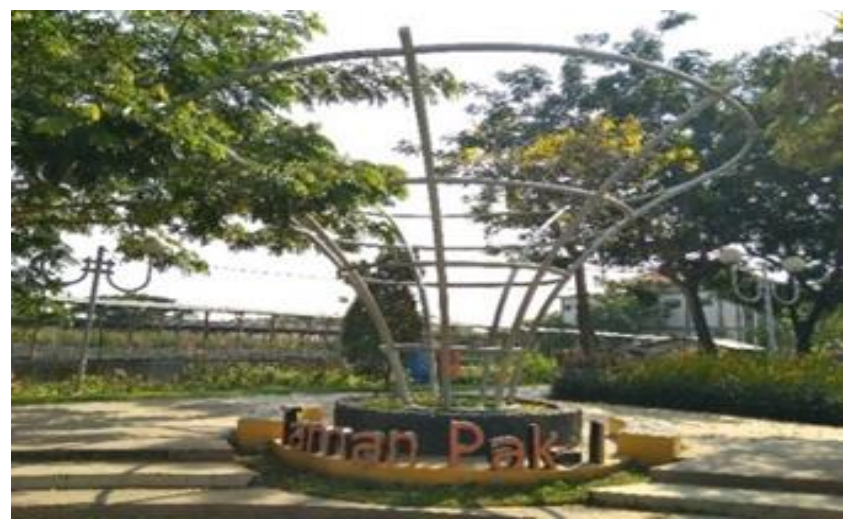

Gambar 7. Penerapan bentuk lingkaran pada sculpture taman Pakal (sumber : hasil observasi, 2018). 
Penataan sitting group dengan bentuk lingkaran memudahkan penggunanya untuk duduk dan berinteraksi satu sama lain. Pola linear dan melingkar juga dapat ditemui dalam penataan sirkulasi taman Pakal (gambar 8).

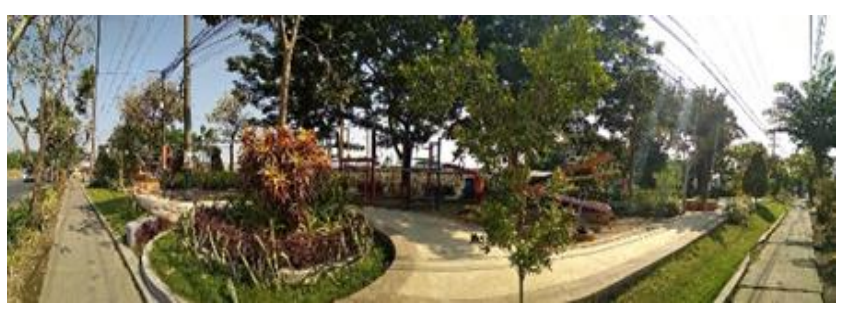

Gambar 8. Bentuk geometris pada pola sirkulasi dan penataan vegetasi (sumber: hasil observasi, 2018)

Adanya pepohonan dan vegetasi mampu membuat pengunjung merasa nyaman dalam beraktivitas di taman. Luas lahan taman Pakal tergolong kecil bila dibandingkan dengan taman lainnya yang ada di kota Surabaya, sehingga taman ini tidak dapat mengakomodir kegiatan pengunjung dalam skala yang besar. Zonasi pada taman ini secara umum terbagi menjadi dua yakni area playground yang berada di tengah tapak dan area taman yang disekelilingnya. Keberadaan playground di tengah tapak memudahkan pengunjung dalam mengawasi anak-anak mereka yang sedang bermain.

Pencahayaan alami pada taman ini didapat dari sinar matahari yang diakomodir dengan naungan berupa pepohonan yang rimbun sehingga panas matahari tidak terlalu menyengat. Selain pepohonan, terdapat vegetasi berupa tanaman bunga-bungaan dan tanaman hias yang berfungsi sebagai penambah estetika. Taman ini beroperasi sampai malam hari, sehingga pencahayan buatan berupa lampu taman sangat penting untuk mengakomodir kegiatan dalam taman.
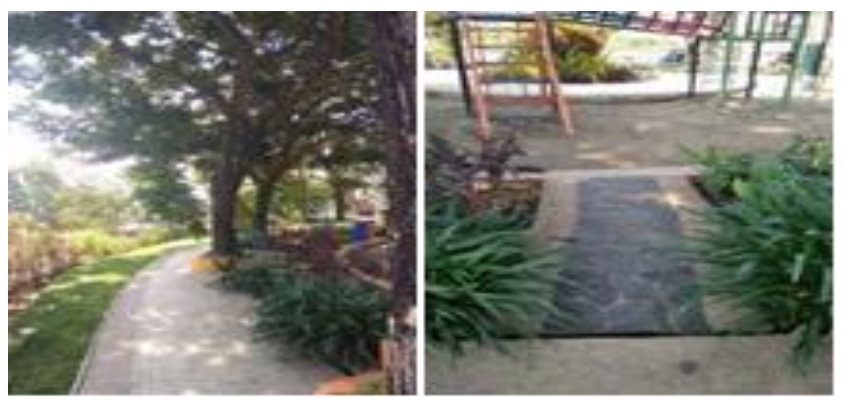

Gambar 9. Sirkulasi dan materialnya di taman Pakal (sumber: hasil observasi, 2018)

Aksesibilitas menuju taman Pakal cukup terbatas karena hanya terdapat satu akses melalui jalan Raya Babat Jerawat. Tidak terdapat pintu masuk khusus, sehingga taman dapat diakses dari sepanjang jalan tersebut. Dengan lebar sekitar 2 meter, jalur sirkulasi dalam taman telah menggunakan material keramik batu dan cor beton dengan tekstur kasar sehingga tidak licin ketika hujan turun (gambar 9).

Elemen lunak pada taman Pakal ini direpresentasikan oleh beberapa jenis tumbuhan bunga-bungaan yang memenuhi taman dan pepohonan yang rindang. Sedangkan elemen keras berupa playground yang dilengkapi dengan tempat sampah sebagai setting fisik untuk mengarahkan pengunjung untuk menjaga kebersihan. Sikap memelihara kebersihan yang merupakan cerminan diri bagi setiap muslim. Selain aktivitas bermain, pengunjung juga dapat melakukan kegiatan piknik di area taman Pakal. Dari hasi observasi, pengunjung yang datang di taman ini cenderung menggunakan pakaian yang sopan sesuai dengan aktivitas yang dilakukan. Pada taman Pakal tidak terdapat signage untuk mengarahkan perilaku pengunjung di dalam taman)

\section{Taman Bulak}

Dengan luas lahan $\pm 7.100 \mathrm{~m}^{2}$ taman Bulak terletak di jalan Abdulatif, Surabaya Utara. Taman Bulak merupakan representasi kegiatan tahsin al ard berupa penghijauan untuk dapat mencapai ihya dan islah. Parameter ruang (space) terpenuhi dengan luasan lahan yang relatif besar dan zonasi yang jelas, memungkinkan pengunjung datang ke taman dalam jumlah yang banyak dengan berbagai aktivitas berbeda pada waktu yang bersamaan. Zonasi pada taman terbagi menjadi tiga, yakni zona taman, zona olahraga dan zona bermain. Pembagian zonasi taman cukup jelas sehingga memudahkan pengunjung untuk melakukan aktivitas yang diinginkan. Ketiga zona dipisahkan oleh sungai kecil dan diberi penghubung berupa jembatan yang menambah daya tarik taman sebagai tempat rekreasi.

Pada taman Bulak ini tidak terdapat sculpture khusus, namun terdapat beberapa jenis vegetasi yang secara dimensi dan kepadatan tampak cukup mendominasi taman dan diletakkan pada bagian tengah tapak sehingga menjadi focal point taman. Dalam penerapan parameter urutan (order) pada prinsip islamic garden, dapat ditemukan bentukanbentukan geometri seperti lingkaran dan lengkungan pada pola sirkulasi, penataan vegetasi, playground dan bentuk sitting group (gambar 10). Bentuk melingkar pada pola sirkulasi memudahkan dalam pengawasan anak-anak bermain di playground dan mudah dalam mengeksplorasi taman. Bentukan geometris lainnya adalah persegi panjang yang terdapat pada lapangan futsal. Masing-masing zona terhubung dengan baik dengan tersedianya jalur sirkulasi berupa perkerasan.

Pencahayaan alami pada taman Bulak didapat dari sinar matahari. Letaknya yang berdekatan dengan pantai Kenjeran membuat taman terasa panas pada siang hari. Naungan yang terdapat pada Taman Bulak 
berupa pepohonan yang cukup rimbun dengan berbagai jenis pohon, pada beberapa spot di taman Bulak terutama pada area sitting group. Pencahayaan buatan didapatkan dari lampu taman dan lampu jalan karena letak taman yang bersebelahan dengan jalan raya yang mengakomodir kebutuhan pencahayaan dalam taman di malam hari.

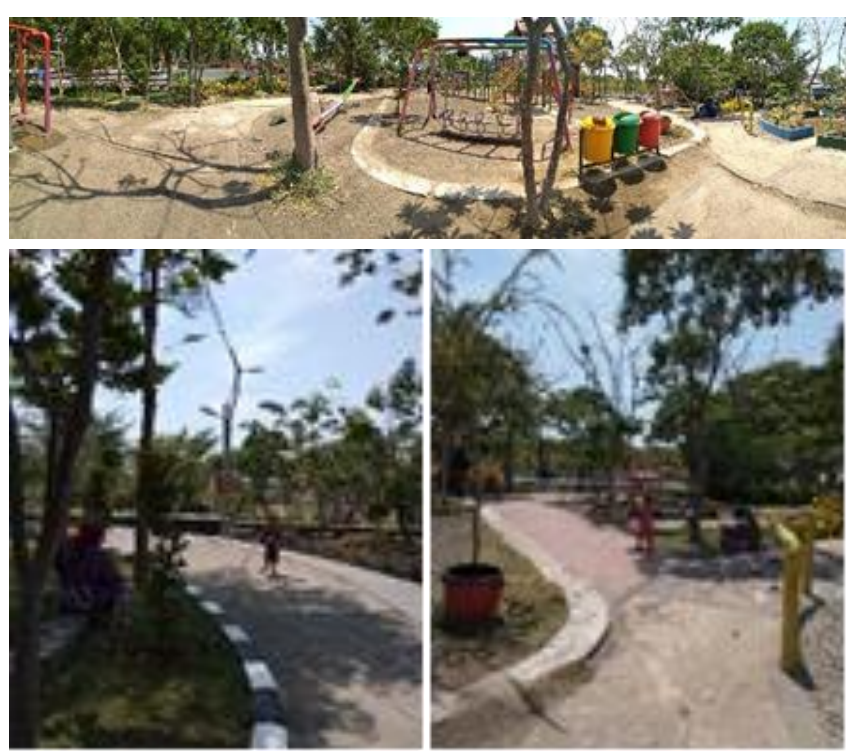

Gambar 10. Pola sirkulasi, penataan vegetasi dan bentuk sitting group (sumber: hasil observasi, 2018)

Parameter movement pada taman Bulak terpenuhi dari sisi titik aksesibilitas dan jalur sirkulasi dalam taman. Aksesibilitas menuju taman Bulak relatif mudah. Untuk mengakses taman Bulak dapat dilakukan menggunakan kendaraan pribadi maupun kendaraan umum. Terdapat dua akses jalan raya menuju ke area taman yaitu dari jalan Abdulatif dan jalan Kyai Tambak Deres. Lebar jalur sirkulasi yang digunakan pengunjung untuk mengekspolasi taman sekitar 1-1,5 meter sehingga dapat dipergunakan oleh dua orang, baik untuk berjalan bersisihan maupun berpapasan. Perkerasan yang digunakan pada jalur sirkulasi ini terbuat dari cor beton.

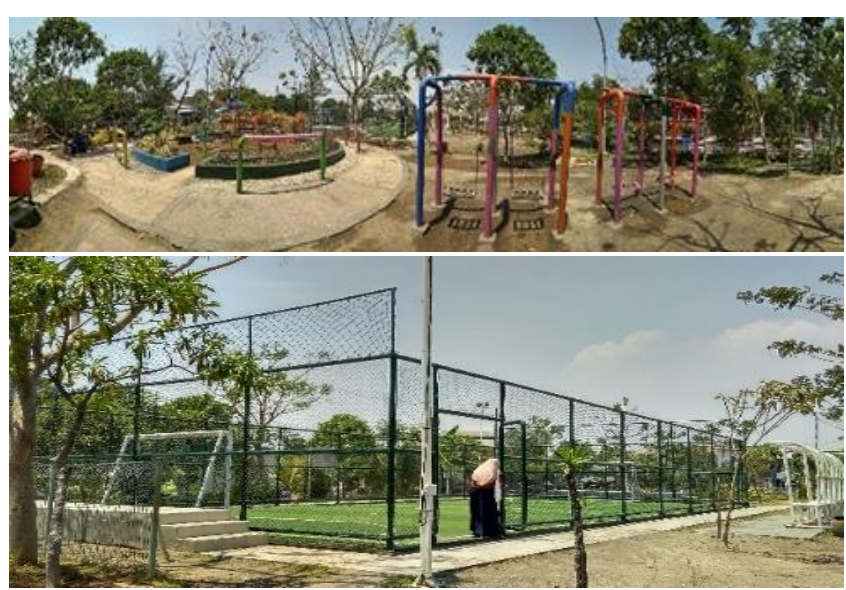

Gambar 11. Sarana playground dan lapangan futsal (sumber: hasil observasi, 2018)
Elemen lunak taman yang tersedia pada taman bulak berupa berbagai tanaman berupa pepohonan dan beraneka ragam bunga khususnya bunga sepatu berwarna merah. Selain itu terdapat elemen air berupa sungai yang memisahkan antara zona taman dengan zona playground dan zona olahraga. Elemen keras yang terdapat pada taman Bulak ini berupa fasilitas lapangan olahraga, playground dan furniture taman (gambar 11). Aktivitas pengunjung pada taman Bulak ini mengalami peningkatan pada sore hari, akhir pekan dan hari libur. Aktivitas-aktivitas yang terdapat pada Taman Bungkul merupakan aktivitas yang tidak menyalahi syariah Islam).

\section{Taman Bungkul}

Taman ini terletak di jalan Taman Bungkul, Darmo, Surabaya bagian selatan. Taman yang pernah mendapatkan penghargaan "The 2013 Asian Townscape Award (ATA)" dari Perserikatan Bangsa Bangsa sebagai Taman Terbaik se-Asia ini diresmikan pada tanggal 21 maret 2007. Penerapan konsep Islamic garden pada taman Bungkul terlihat dari bentukan lahan yang berbentuk geometris terhadap lingkungan sekitar. Pola geometris pada taman Bungkul juga terlihat pada bentukan taman, penataan vegetasi dan sirkulasi melingkar pada beberapa area pusat seperti pada area plaza taman berupa amphiteatre terbuka yang cukup besar (gambar12).

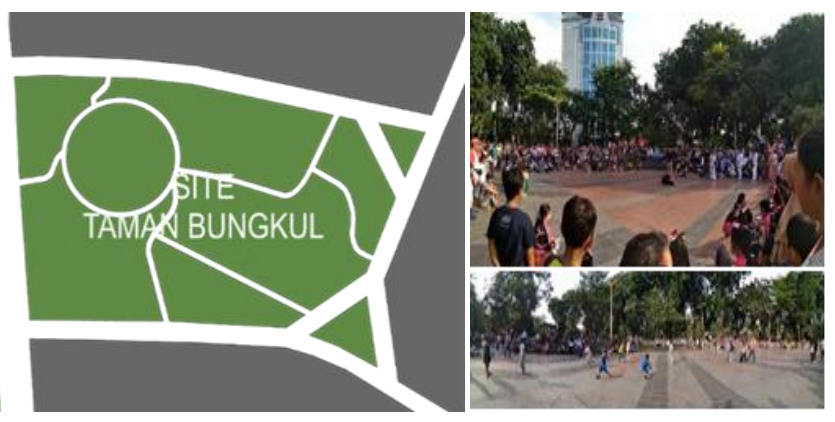

Gambar 12. Bentukan tapak Taman Bungkul serta suasana amphitheatre terbuka sebagai pusat kegiatan (sumber: hasil observasi, 2018)

Zonasi taman terbagi dengan jelas berdasar aktivitas yang ada di dalamnya. Terdapat zona religi pada taman Bungkul yakni berupa makam yang terletak di dalam taman namun dibatasi pemisah sehingga aktivitas di taman dan makam tidak saling mengganggu. Dari hasil observasi, adanya makam di taman tidak dipergunakan pengunjung untuk melakukan ritual yang bersifat menyimpang dari ajaran Islam, walaupun banyak didatangi pengunjung yang hendak melakukan ziarah. Pada beberapa titik taman ditemui sejumlah sculpture dan patung, dimana salah satunya memiliki bentuk manusia, yang terletak area kolam 9gmbar 13). Hal ini tidaklah sejalan dengan prinsip Islamic garden yang melarang bentukan makhluk hidup sebagai hiasan. 


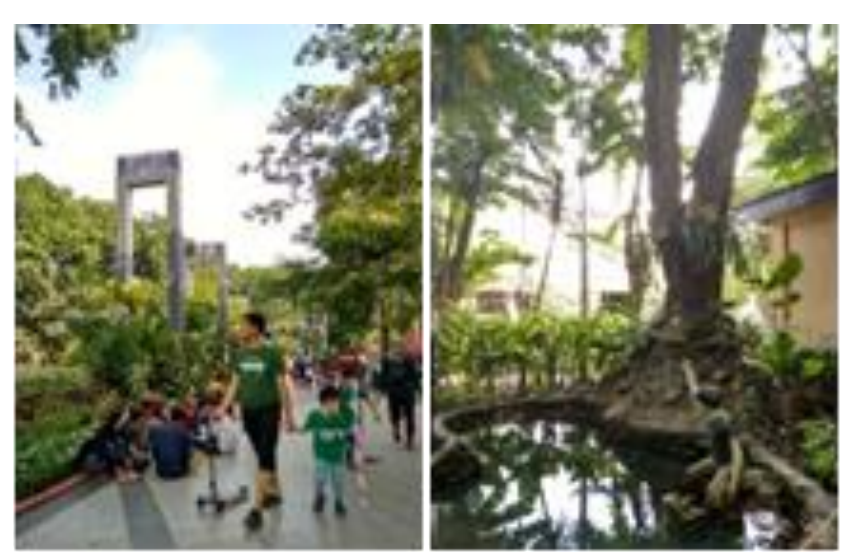

Gambar 13. Sculpture non makhluk hidup (kiri);dan makhluk hidup (kanan) (sumber: hasil observasi, 2018)

Pencahayaan di Taman Bungkul didapat dari sinar matahari yang di filter oleh vegetasi dalam taman Bungkul dan berfungisi menjadi peneduh bagi pengunjung. Pencahayaan buatan didapat dari lampu taman dan lampu jalan sehingga memungkinkan pengunjung melakukan kegiatan dalam taman pada malam hari. Terdapat beberapa titik lampu yang menerangi taman dan berfungsi maksimal pada malam hari.

Taman Bungkul memiliki banyak akses pencapaian yaitu dari Jalan Raya Malang - Surabaya, jalan Progo, jalan Taman Bungkul, dan jalan Serayu. Kemudahan akses jalan didukung dengan kemudahan moda transportasi, baik umum maupun pribadi. Pada jalur sirkulasi, lebar jalan yang digunakan pengunjung untuk mengeksplorasi taman mencapai 1.5 - 2.5 meter. Material yang digunakan untuk sirkulasi ini terbuat dari keramik kasar dan paving block (gambar 14). Parameter pergerakan (movement) pada taman Bungkul terpenuhi dari sisi kemudahan aksesibilitas dan kemudahan sirkulasi dalam taman.

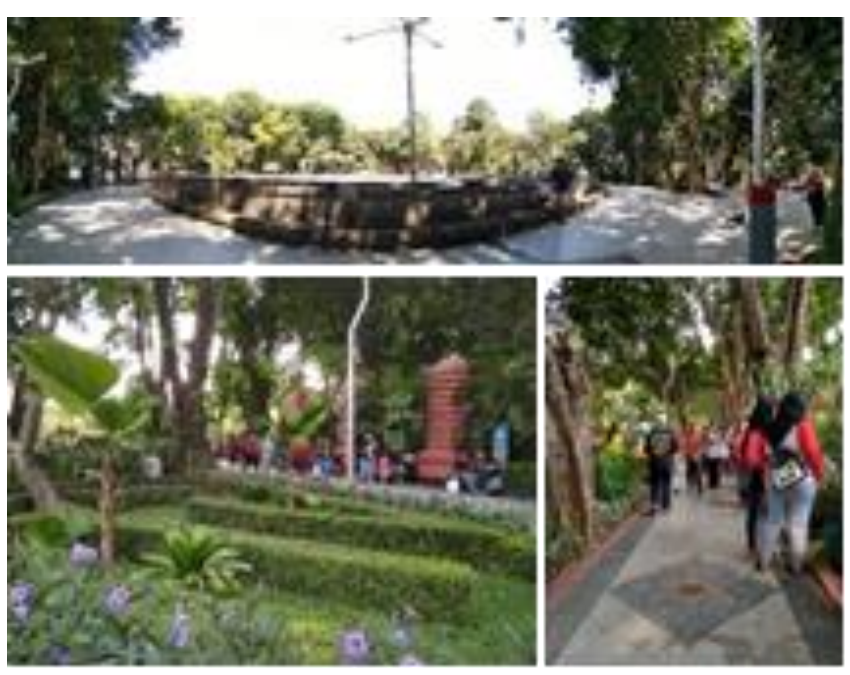

Gambar 14. Penataan furniture, vegetasi dan pola keramik pada jalur sirkulasi (sumber: hasil observasi, 2018)
Terdapat elemen lunak pada taman Bungkul, diantaranya vegetasi dan air mancur di sisi plaza dan di area bermain anak. Elemen keras pada taman Bungkul berupa toilet, makam, playground, mushola dan sentra Pedagang Kaki Lima (PKL). Masing-masing elemen ini masih berfungsi dengan baik sehingga dapat dipergunakan pengunjung sebagai pendukung aktivitas dalam taman.
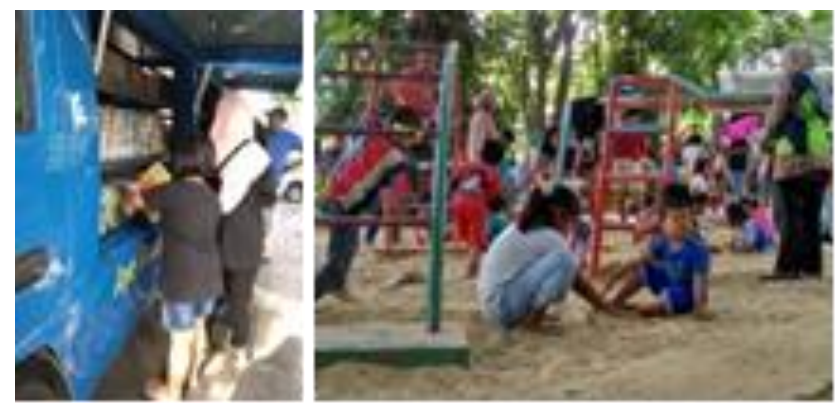

Gambar 15. Fasilitas Perpustakaan (kiri) dan playground (kanan) di Taman Bungkul (sumber: hasil observasi, 2018)

Aktivitas di taman Bungkul mengalami peningkatan terutama pada waktu akhir pekan dan hari libur. Beragam aktivitas dilakukan di Taman Bungkul misalnya adanya Car Free Day (CFD), didalamnya pengunjung dapat berolah raga, penggalangan dana untuk korban bencana alam, wisata kuliner dan tempat berkumpulnya berbagai komunitas seperti komunitas pencinta satwa, skateboard dan lain - lain. Selain fasilitas bermain, terdapat fasilitas belajar bagi anakanak yaitu perpustakaan keliling (gambar 15). Fasilitas ini disediakan bagi anak-anak untuk menumbuhkan minat membaca bagi anak. Untuk tetap menjaga keamanan, pihak pengelola memasang CCTV sebagai fasilitas keamanan. Selain CCTV, juga terdapat signage atau rambu-rambu sebagai batasan dalam berperilaku diantaranya larangan membuang sampah sembarangan, larangan berpacaran, dilarang menggunakan sepeda pada area tertentu, dilarang memetik bunga dan lain-lain.

\section{Taman Prestasi}

Berlokasi di jalan Ketabang Kali no.6, Ketabang, Surabaya bagian pusat, taman ini dibangun pada tahun 1992 dan diresmikan pada tahun 1995 dan berbentuk asimetris (gambar 16). Dengan bentukan geometris tapak yang asimetris maka parameter urutan (order) tidak terpenuhi. Keseimbangan antara RTH dan RTNH cukup terpenuhi dari sisi luasan ruang hijau terhadap luasan taman. Hal ini menyebabkan taman terasa sejuk dan asri. Luasan taman yang cukup sehingga dapat mengakomodir kegiatan pengunjung. Pada saat observasi, selain kegiatan yang bersifat reguler ditemui juga berbagai aktifitas-aktifitas lain seperti kegiatan diklat Tim Satpol PP kota Surabaya, dan latihan olahraga dayung oleh sekelompok anggota Pramuka. 


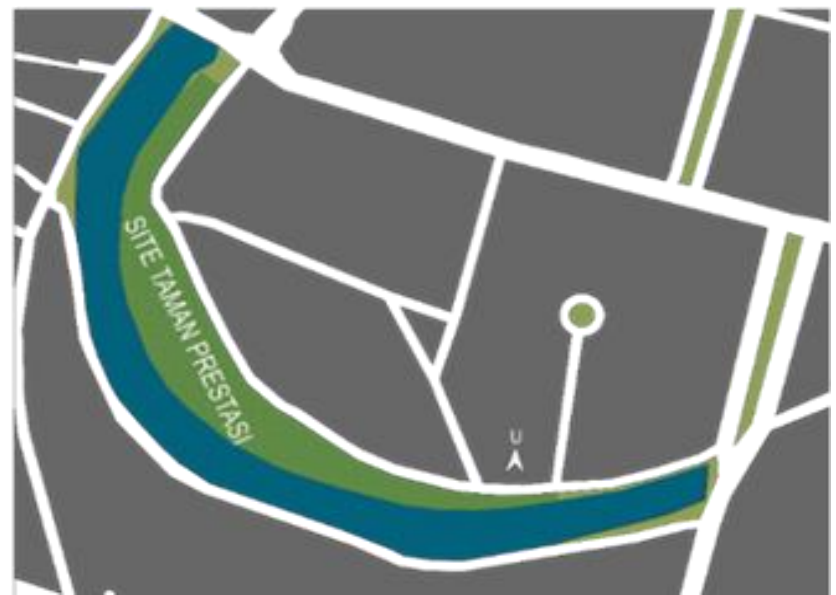

Gambar 16. Bentuk tapak Taman Prestasi (sumber: hasil sketsa ulang peneliti, 2018)

Secara garis besar zonasi pada taman Prestasi terbagi menjadi dua zonasi yang jelas, yakni zonasi utara dan zonasi selatan. Zonasi utara digunakan untuk wahana bermain anak, di bagian pusat taman terdapat sculpture, dan di sebelah selatan digunakan untuk wahana air, monumen pesawat dan kantin. Tempat bermain anak tersebar lebih banyak di area utara, namun juga beberapa tersebar hingga ke area Selatan. Pada taman Prestasi terdapat monumen penghargaan Wahana Tata Nugraha dan Adipura Kencana. Monumen-monumen ini ditujukan sebagai pengingat kepada warga Surabaya untuk senantiasa menjaga dan meningkatkan kualitas lingkungan kota Surabaya.

Taman Prestasi memiliki pola geometris pada penataan vegetasinya, berbentuk lingkaran dan memanjang. Selain itu pola geometris teraplikasi pada penataan jalur sirkulasinya, yang dibuat linier (gambar 17). Terdapat naungan pada taman ini yang ditumbuhi tanaman rambat maupun diatapi dengan atap berbentuk membran. Taman ini dapat di akses hingga pukul 21.00 WIB. Pencahayaan buatan didapatkan dari adanya perletakan titik lampu untuk mengakomodir kegiatan dalam taman dan keamanan dalam taman.

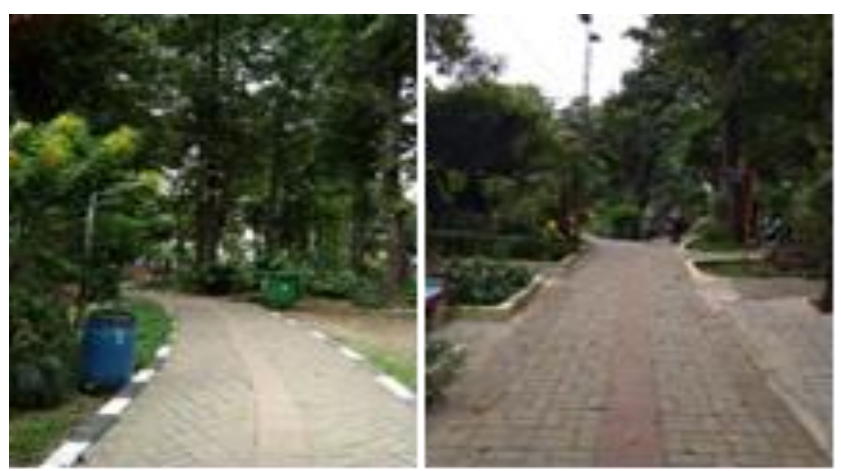

Gambar 17. Penataan jalur sirkulasi dan vegetasi (sumber: hasil observasi, 2018)
Aksesibilitas menuju Taman Prestasi hanya dapat dilakukan dari jalan Basuki Rahmat karena jalan Ketabang Kali merupakan jalur satu arah. Moda transportasi yang dapat digunakan mengakses taman adalah kendaraan umum dan kendaraan pribadi. Taman memiliki satu pintu masuk utama, namun terdapat pintu kecil untuk akses di bagian sisi taman lainnya. Lebar jalur sirkulasi untuk pengguna taman Prestasi sebesar 2,5 meter dan bisa digunakan untuk 2-3 orang jalan berdampingan. Material perkerasan pada jalur sirkulasi ini menggunakan bahan material paving.

Pada mulanya, Taman Prestasi dibangun dengan menitikberatkan pada fokus untuk menambah dan menumbuhkan tanaman, sehingga pepohonan dan tanaman yang ada saat ini jumlahnya cukup banyak. Sedangkan saat ini fokus utama Pemerintah Kota terhadap taman Prestasi lebih menitik beratkan pada penambahan jenis kegiatan dalam taman sehingga fasilitas yang ada dalam taman mengalami penambahan untuk menarik minat masyarakat berkunjung. Vegetasi berupa tanaman yang disusun berkelompok sehingga menciptakan titik-titik naungan pada area taman ini (gambar 18).

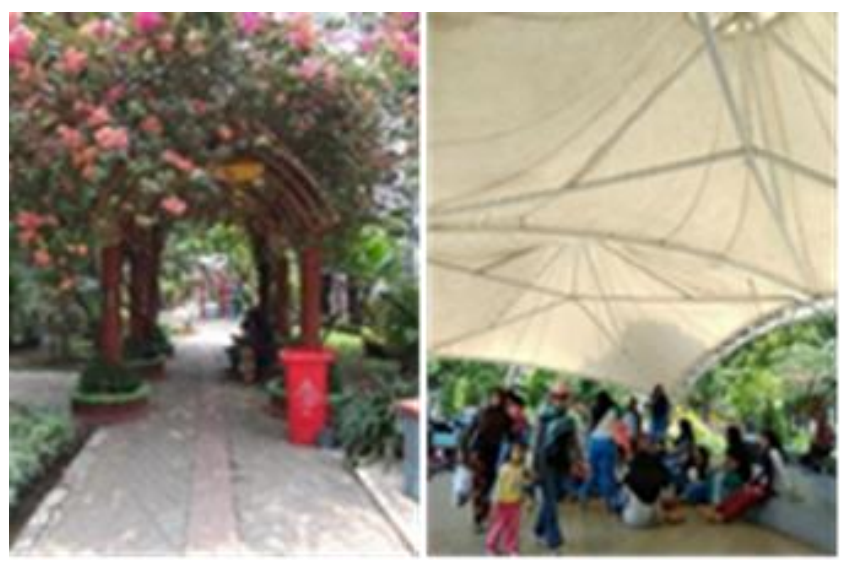

Gambar 18. Naungan (kiri) Shelter berupa dermaga (kanan) (sumber: hasil observasi, 2018)
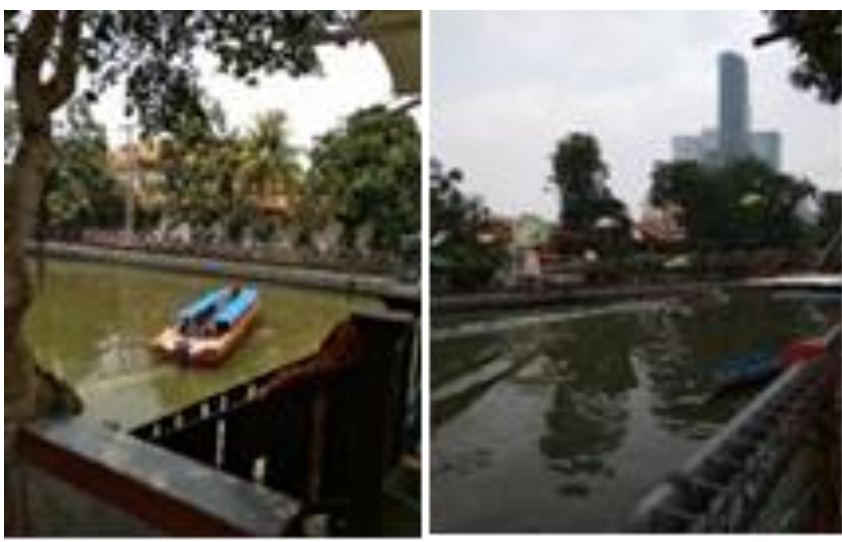

Gambar 19. Elemen air (sumber:hasil observasi, 2018) 
Terdapat pula beberapa fasilitas pendukung sitting group dan playground yang tersebar ke berbagai area taman. Terdapat pula fasilitas kantor, tempat untuk belajar komputer dan taman bacaan, toilet, mushola, amphitheater, gazebo dan lain sebagainya. Pada taman ini terdapat fasilitas kebersihan berupa tempat sampah yang sudah tersebar pada area taman serta terdapat fasilitas keamanan yang berada di bagian pintu utama taman. Taman Prestasi memiliki wahana perahu karena letaknya berada di sisi sungai Ketabang (gambar 19). Aktivitas pengunjung yang dilakukan di taman Prestasi ini lebih padat pada saat akhir pekan maupun hari libur. Pengunjung melakukan aktivitas diantaranya rekreasi, komunitas hobi, serta aktivitas kuliner. Taman Prestasi juga menjadi tempat untuk menunggu antrean wahana wisata perahu di sungai Ketabang. Pengunjung taman Prestasi rata-rata berpakaian sopan, sesuai dengan aktivitas yang dilakukan pada taman. Terdapat signage pada Taman Prestasi yang berisi himbauan untuk mencegah pengunjung melakukan hal yang dilarang di dalam taman.

\subsection{Hasil rekapitulasi analisis eksisting parameter Islamic garden pada lima taman kota Surabaya}

Dari hasil amatan terhadap sembilan prinsip Islamic Garden dengan duapuluh delapan parameter pada lima taman kota di Surabaya dapat dirangkum seperti pada tabel 2 berikut.

Tabel 2. Rekap hasil analisis parameter

\begin{tabular}{|c|c|c|c|c|c|}
\hline Prinsip dan Parameter & Flora & Pakal & Bulak & Bungkul & Prestasi \\
\hline \multicolumn{6}{|l|}{ Urutan (Order) } \\
\hline Taman memiliki bentuk geometris & $\sqrt{ }$ & $\sqrt{ }$ & $\sqrt{ }$ & $\sqrt{ }$ & - \\
\hline Luasan RTH dan RTNH yang seimbang & $\sqrt{ }$ & $\sqrt{ }$ & $\sqrt{ }$ & $\sqrt{ }$ & $\sqrt{ }$ \\
\hline \multicolumn{6}{|l|}{ Ruang (Space) } \\
\hline Luas taman dapat digunakan pengunjung bersama dalam satu waktu. & $\sqrt{ }$ & - & $\sqrt{ }$ & $\sqrt{ }$ & $\sqrt{ }$ \\
\hline Zonasi taman yang jelas. & $\sqrt{ }$ & $\sqrt{ }$ & $\sqrt{ }$ & $\sqrt{ }$ & $\sqrt{ }$ \\
\hline \multicolumn{6}{|l|}{ Bentuk (Form) } \\
\hline sculpture yang menyerupai makhluk hidup & - & - & - & $\sqrt{ }$ & - \\
\hline sculpture yang tidak menyerupai makhluk hidup & $\sqrt{ }$ & $\sqrt{ }$ & - & $\sqrt{ }$ & $\sqrt{ }$ \\
\hline peninggalan bersejarah & - & - & - & $\sqrt{ }$ & $\sqrt{ }$ \\
\hline \multicolumn{6}{|l|}{ Pola (Pattern) } \\
\hline Penataan vegetasi memiliki pola geometris & $\sqrt{ }$ & $\sqrt{ }$ & $\sqrt{ }$ & $\sqrt{ }$ & $\sqrt{ }$ \\
\hline Penataan jalur sirkulasi memiliki pola geometris & $\sqrt{ }$ & $\sqrt{ }$ & $\sqrt{ }$ & $\sqrt{ }$ & $\sqrt{ }$ \\
\hline \multicolumn{6}{|l|}{ Cahaya (Light) } \\
\hline vegetasi sebagai naungan bagi pengunjung taman & $\sqrt{ }$ & $\sqrt{ }$ & $\sqrt{ }$ & $\sqrt{ }$ & $\sqrt{ }$ \\
\hline shelter buatan sebagai naungan bagi pengunjung taman & $\sqrt{ }$ & - & - & $\sqrt{ }$ & $\sqrt{ }$ \\
\hline lampu taman & $\sqrt{ }$ & $\sqrt{ }$ & $\sqrt{ }$ & $\sqrt{ }$ & $\sqrt{ }$ \\
\hline \multicolumn{6}{|l|}{ Pergerakan (Movement) } \\
\hline Adanya lebih dari satu titik aksesibilitas menuju taman & $\sqrt{ }$ & - & $\sqrt{ }$ & $\sqrt{ }$ & $\sqrt{ }$ \\
\hline Adanya sirkulasi untuk mengeksplorasi taman & $\sqrt{ }$ & $\sqrt{ }$ & $\sqrt{ }$ & $\sqrt{ }$ & $\sqrt{ }$ \\
\hline \multicolumn{6}{|l|}{ Elemen Taman (Garden Element) } \\
\hline Vegetasi berupa tanaman bunga pada taman & $\sqrt{ }$ & $\sqrt{ }$ & $\sqrt{ }$ & $\sqrt{ }$ & $\sqrt{ }$ \\
\hline Vegetasi berupa tanaman buah pada taman & - & - & - & - & - \\
\hline Susunan vegetasi dan menciptakan naungan & $\sqrt{ }$ & - & - & - & $\sqrt{ }$ \\
\hline Adanya beberapa jenis satwa di dalam taman & $\sqrt{ }$ & - & - & - & - \\
\hline sitting group & $\sqrt{ }$ & $\sqrt{ }$ & $\sqrt{ }$ & $\sqrt{ }$ & $\sqrt{ }$ \\
\hline Elemen air & $\sqrt{ }$ & - & $\sqrt{ }$ & $\sqrt{ }$ & $\sqrt{ }$ \\
\hline Fasilitas bangunan yang digunakan bersama dalam taman & $\sqrt{ }$ & - & - & $\sqrt{ }$ & $\sqrt{ }$ \\
\hline Fasilitas tempat sampah & $\sqrt{ }$ & $\sqrt{ }$ & $\sqrt{ }$ & $\sqrt{ }$ & $\sqrt{ }$ \\
\hline Fasilitas keamanan & $\sqrt{ }$ & - & $\sqrt{ }$ & $\sqrt{ }$ & $\sqrt{ }$ \\
\hline \multicolumn{6}{|l|}{ Pengguna (User) } \\
\hline Pengunjung datang untuk berekreasi & $\sqrt{ }$ & $\sqrt{ }$ & $\sqrt{ }$ & $\sqrt{ }$ & $\sqrt{ }$ \\
\hline Pengunjung datang untuk makan di taman & $\sqrt{ }$ & $\sqrt{ }$ & $\sqrt{ }$ & $\sqrt{ }$ & $\sqrt{ }$ \\
\hline signage untuk mencegah perilaku yang tidak diperkenankan & $\sqrt{ }$ & - & $\sqrt{ }$ & $\sqrt{ }$ & $\sqrt{ }$ \\
\hline Pakaian pengunjung yang sopan dan sesuai aktifitas & $\sqrt{ }$ & $\sqrt{ }$ & $\sqrt{ }$ & $\sqrt{ }$ & $\sqrt{ }$ \\
\hline fasilitas beribadah & $\sqrt{ }$ & - & - & $\sqrt{ }$ & $\sqrt{ }$ \\
\hline Total Parameter Terpenuhi & $25 / 28$ & $15 / 28$ & $19 / 28$ & $25 / 28$ & $23 / 28$ \\
\hline
\end{tabular}

Sumber: hasil analisis (2018) 
Dari tabel 2 dapat dilihat bahwa Taman Flora dan taman Bungkul menjadi taman dengan parameter Islamic garden yang paling banyak terpenuhi ( 25 dari 28 parameter), disusul berturut-turut oleh Taman Prestasi, Taman Bulak dan Taman Pakal.

Parameter terbanyak yang sudah diaplikasikan pada setiap taman adalah berkaitan dengan keseimbangan antara ruang terbuka hijau dan ruang terbuka non hijau. Taman-taman yang diteliti masingmasing berfungsi menjadi ruang terbuka hijau publik dan paru-paru kota. Dua taman seperti taman Flora dan Taman Prestasi khusus dibuat untuk menjadi pusat pembibitan tanaman yang dilengkapi dengan sarana rekreasi warga. Selain itu, penggunaan bentuk geometri pada masing-masing taman masih menjadi pilihan untuk diterapkan baik pada elemen keras maupun elemen lunak taman. Bentuk persegi memudahkan pengunjung untuk melihat pola sirkulasi sedangkan bentuk lingkaran yang diterapkan pada sitting group memudahkan pengunjung dalam berinteraksi. Masing-masing taman telah memiliki zonasi yang jelas sehingga memudahkan pengunjung beraktivitas. Fasilitas masing-masing taman dapat mengakomodir kebutuhan pengunjung selama beraktivitas dalam taman

Salah satu parameter yang terbanyak tidak ditemui pada taman-taman yang diteliti adalah pada parameter adanya sculpture atau patung dengan bentukan menyerupai makhluk hidup serta terdapat peninggalan bersejarah di area taman yang hanya ditemukan pada taman Bungkul saja. Namun kedua hal tersebut tidak lantas menjadikan pengunjung melakukan aktivitas syirik yang dilarang oleh agama Islam dan norma sosial. Keberadaan makam dan patung menjadi dua komponen yang terintegrasi terhadap taman Bungkul dan tidak saling mengganggu aktivitas satu dengan lainnya.

Parameter shelter buatan sebagai naungan dari cahaya matahari di Taman Bulak dan taman Pakal juga tidak diterapkan. Hal ini menyebabkan pengunjung kurang dapat beraktivitas dengan nyaman pada siang hari karena vegetasi yang terdapat di kedua taman tersebut dirasa belum cukup untuk menaungi pengunjung taman yang beraktivitas di dalamnya. Perlunya desain shelter buatan pada kedua taman ini dapat dijadikan rekomendasi untuk peningkatan kualitas taman Bulak dan taman Pakal.

Secara umum, kelima taman dibuat dengan maksud tahsin al ard atau penghijauan di bumi. Sehingga masing-masing taman memiliki luasan RTH dan RTNH yang seimbang dan taman berfungsi sebagai paru-paru kota. Masing-masing kegiatan memiliki nilai positif dan terwadahi dengan baik di ruang terbuka publik yang disediakan oleh pemerintah Kota. Dalam hal ini taman telah menjadi ruang publik yang bertujuan untuk ihya dan islah, yaitu meningkatkan pertanian untuk peningkatan kemakmuran di bumi, baik secara materiil maupun secara spiritual

\section{KESIMPULAN}

Islam memiliki sebuah konsep taman sebagai gambaran syurga yang dijelaskan secara lugas dalam Al-Qur'an. Konsep tersebut sering disebut sebagai Islamic Garden. Dengan penggunaan konsep Islamic Garden ini diharapkannya taman-taman yang ada khususnya di kota Surabaya menjadi taman yang berprinsip islami. Adapun prinsip-prinsip yang menjadi parameter dalam melakukan observasi yaitu Urutan, ruang, bentuk, pola, cahaya, pergerakan, elemen taman serta pengguna.

Dari hasil observasi dan analisis diketahui bahwa urutan parameter dari yang paling terpenuhi hingga kurang terpenuhi yaitu: Pola adalah satu-satunya parameter yang terpenuhi di lima objek taman; Urutan, Ruang, dan pergerakan terpenuhi di 4 dari 5 taman; Cahaya dan pengguna terpenuhi di 3 dari 5 taman; Bentuk hanya terpenuhi di taman Bungkul. Sedangkan urutan taman yang telah menerapkan konsep taman islami yaitu:Taman Flora dengan poin yang diperoleh 25 dari 28 poin; Taman Bungkul dengan 25 dari 28 poin; Taman Prestasi dengan 23 dari 28 poin; Taman Bulak dengan 19 dari 28 poin; Taman Pakal dengan 15 dari 28 poin.

Penambahan Shelter buatan untuk menaungi pengunjung dalam taman yaitu pada taman Pakal dan Taman Bulak perlu diakomodir. Selain Itu, perlu vegetasi tambahan terutama di taman Bulak karena kondisi taman yang cukup gersang, di taman pada taman-taman yang belum memiliki signage himbauan dan larangan seperti pada taman Bulak dan taman Pakal perlu ditambahan signage.

\section{DAFTAR PUSTAKA}

BPS Provinsi Jawa Timur. (2017). Jumlah Penduduk Menurut Kabupaten/Kota dan Agama yang Dianut di Provinsi Jawa Timur, 2016. Retrieved October 31, 2018, from https://jatim.bps.go.id/dynamictable/2017/10/09/ 120/jumlah-penduduk-menurut-kabupaten-kotadan-agama-yang-dianut-di-provinsi-jawa-timur2016.html

Francis, J., Giles-Corti, B., Wood, L., \& Knuiman, M. (2012). Creating sense of community: The role of public space. Journal of Environmental Psychology, 32(4), 401-409. doi:10.1016/j.jenvp.2012.07.002

Iswari, A. N. (2014). Strategi Dinas Kebersihan dan Pertamanan Kota Surabaya dalam Pengelolaan Ruang Terbuka Hijau (RTH) untuk Mewujudkan Pembangunan Berkelanjutan dan Berwawasan Lingkungan. Jurnal Kebijakan Dan Manajemen Publik, 1. 
Jannah, M., Mugnisjah, W. Q., \& Gunawan, A. (2016). Kajian Konsep Taman Islam Berdasarkan Al Quran dan Hadits. El Harakah, 17(1), 1-17. doi:10.18860/el.v17i1.3082

Viva, T. (2018). Risma Berambisi Bangun Lebih Banyak Taman hingga Pinggiran Surabaya. Retrieved January 3, 2019, from https://www.viva.co.id/berita/nasional/110231 3-risma-berambisi-bangun-lebih-banyaktaman-hingga-pinggiran-surabaya

Walidaen, M. B., Utami, N. W. F., \& Yusiana, L. S. (2017). Perencanaan Taman Islam pada Lansekap Islamic Center Provinsi NTB. Jurnal Arsitektur Lansekap, 77-86. doi:10.24843/JAL.2017.v03.i01.p09

Yolanda, G., \& Masnuna, M. (2015). Buku Infografis Taman Kota di Surabaya. Createvitas: Jurnal IImiah Desain Komunikasi Visual, 4(2), 275 p.$290 \mathrm{p}$. 